\title{
Additional External Costs Analysis and Environmental CBA
}

\author{
Zinaida Dimitrijević ${ }^{1, *}$ and Iris Salihbegovic ${ }^{2}$ \\ ${ }^{1}$ Public Enterprise Elektroprivreda BiH, Vilsonovo Setaliste 15, Sarajevo, BiH, Bosnia \\ ${ }^{2}$ Public Enterprise Elektroprijenos BiH, a.d. Banja Luka, BiH, Bosnia
}

\begin{abstract}
The sustainable development requires policies and measures which negative impacts would not be spilled over on another area or has trends that pose severe or irreversible threats to future quality of life. The environmental costs-benefits analysis (CBA) as well as multi criteria analyse are the most common used methods for the decision making processes including the approved methodology for quantifying external costs especially regarding air quality. Since the reducing one type of external cost generates another external cost due to fact that the problem is only shifted from the one area to the another CBA is not enough for the decision making process because external cost of a future implemented measure isn't considered. By the usage of Life-cycle costing (LCC), a tool which evaluates the costs of an new installed asset imposed trough the adopted policy or measure throughout its life cycle, it is possible beside the common costs for conducting CBA include also the end-of-life and disposal costs as the new installed asset's external costs too. These costs have to be calculated and added to the cost side of CBA before comparing to the benefits. So, for the purpose of decision making process of the retrofitting existing thermal power plants with DeSOx such calculation has been done as a case study for one thermal power plant in Bosnia and Herzegovina highlighting overall costs and benefits of the DeSOx installation.
\end{abstract}

Keywords: Environmental CBA, external costs, LCC, retrofitting, cogeneration.

\section{INTRODUCTION}

External cost's application, among others, is in a very important field - performance of environmental cost-benefit analyses (CBA) for the policies and measures that aim to reduce environmental and health impacts. Thus policies and measures for reducing environmental pollution generally imply additional costs for industry and consumers so it is important for the acceptance of the measure to show to the stakeholders that the benefits, for example reduced health risks, outweigh or justify the costs. Usually benefits are expressed as avoided external costs. To calculate the avoided external costs, it is necessary to create at least two scenarios: a business as usually (BAU) or baseline scenario, which describes a condition without the implementation of any measure or policy and a scenario with included measure. Impacts expressed as external costs for the two scenarios are considered. The benefits then can be compared with costs. If benefits are larger than costs, the policy or measure is beneficial for society's welfare [1]. But, when one calculates costs of proposed policies or measures the common practice is to calculate only investment and operative and maintenance (O\&M) costs of abatement equipment and then costs are compared to the benefits. External costs occurring, due to for example installing, operating and decommission of such utilities as DeSOx or DeNOx, are not taken into account. So, to

*Address correspondence to this author at the Public Enterprise Elektroprivreda $\mathrm{BiH}$, Vilsonovo Setaliste 15, Sarajevo, BiH, Bosnia; Tel: +38733751765; Fax: +38733751707; E-mail: z.dimitrijevic@elektroprivreda.ba prevent shifting of burdens from one area to another, it is needed that the whole life cycle be taken into account [2]. When existing plants (with only a decade of operation time left) are considered for retrofitting by DeSOx or DeNOx then external costs occurring trough life cycle of new installed equipment should be analysed and added in assessment. Life Cycle Sustainability Assessment is presented as:

\begin{tabular}{|c|c|}
\hline \multicolumn{2}{|c|}{ LCSA=LCA+LCC+SLCA } \\
\hline $\begin{array}{c}\text { LCSA-Life Cycle Sustainability } \\
\text { Assessment }\end{array}$ & LCC-Life Cycle Costing \\
$\begin{array}{c}\text { LCA-(Environmental) Life Cycle } \\
\text { Assessment }\end{array}$ & $\begin{array}{c}\text { SLCA-Social Life Cycle } \\
\text { Assessment }\end{array}$ \\
\hline
\end{tabular}

While environmental LCA has been in use since the 1960 , social LCA is still in the development. SLCA assesses socio-economic impacts found along the life cycle and complements LCSA with socio and socioeconomic aspect [3]. Only Environmental LCC is relevant in this paper for conducting CBA because it is based on the financial valuation.

\section{METHODS}

Environmental CBA is used and two scenarios have been compared: the first -without any abatement equipment; the second - with applied DeSOx and DeNOx. Electricity generation external costs for the all units in Bosnia and Herzegovina $(\mathrm{BH})$ have been calculated using methodology ExternE i.e. software EcoSense Web [4]. As the emitted pollutants such as $\mathrm{NMVOC}, \mathrm{NH}_{3}$, and heavy metals from thermal power plants are not measured in $\mathrm{BH}$ costs arising due to 
these emissions cannot be calculated. Impacts of emitted pollutants can be calculated on different spatial scales, i.e. local (50 km around the emission source), regional (Europe-wide) and (northern) hemispheric scale. Used version of EcoSense Web was developed within the European Commission projects NEEDS and CASES. EcoSenseWeb model uses results of three air transport models completely integrated into the system. The reference environment database provides receptor specific data on administrative units. Receptor data are available for population, production of various crop types, total agricultural area and building materials and land use data. Investment and OM costs are calculated using data from "Study to develop the design for reduction of Sulphur dioxide and Nitrogen oxide emissions at Kakanj TPP" [5] and "Integrated pollution prevention and control - Reference document on economics and cross-media effects" [6]. Used discount rate is $9.3 \%$ as this discount rate is recommended for $\mathrm{BH}$ energy sector's condition by KEMA study [5]. According Eyre, N. [7] the use of cogeneration reduces fossil fuel damages and depending on the methodology for apportioning emissions, cogeneration of electricity therefore reduces damages by $20-50 \%$. So, for thermal power plants which work in cogeneration regime external costs are decreased in this case and then these values are compared to the benefits. Also, by using LCC some of external costs are calculated and added to the cost side of CBA before comparing to the benefits. From scheme of Environmental LCC it is obvious that there is end-of-life cost which has to be paid when it comes to decommission of equipment. Also, in environmental LCC externalities are important and its importance is relevant for society, so all costs should be taken into account in CBA. Scheme of Environmental LCC structure [8]:

For some units such as Unit 6 and Unit 7 of Thermal Power Plant Kakanj (TPP K) there are available data concerning retrofit with DeSOx so authors have considered external costs occurring due to the future operation of DeSOx that can be monetized. External costs taken into account are from Life Cycle Assessment of lime production [9] and operation of DeSOx [10].

\section{DATA AND RESULTS}

In Bosnia and Herzegovina (BH), $75 \%$ of emission which causes environmental impacts in to the air comes from coal burning. Lignite and brown coal provide the bulk of the country's energy supply and energy generation, accounting $54 \%$ of both. In $\mathrm{BH}$ four thermal plants are operating: TPP Tuzla $(715 \mathrm{MW})$ and TPP Kakanj (460 MW), TPP Ugljevik (300 MW) and TPP Gacko (300 MW). In Table 1 general thermal plant's data in $\mathrm{BH}$ are given. Due to years of operation three units, TPPT U3 and U4, TPPK U5, are not considered for retrofit.

A complete accounting of external costs should involve a LCA, i.e. a complete inventory of the emissions over the entire chain of processes involved in the activity. For the fossil fuel chains the greater part of the external costs comes from air pollutants emitted by the power plant, the main impact categories being global warming and public health [13]. Since this paper deals with investments in DeSOx and DeNOx the impact of global warming is not taken into account for calculating external costs (see Figure 1).

It has to be mentioned that EcoSense Web has two scenarios available regarding pollutant toxicity PPM_E_SIA which denotes equal toxicity of all pollutants and PPM_D_PPM toxicity denotes different toxicity for considered pollutants. For $\mathrm{BH}$ case PPM_D_SIA toxicity is used. Further explanation of toxicity scenario choice can be found in [14]. In EcoSense Web the user can choose between two reference scenarios: the EMEP 2010 or EMEP 2020 emission scenario. In this paper the EMEP 2010

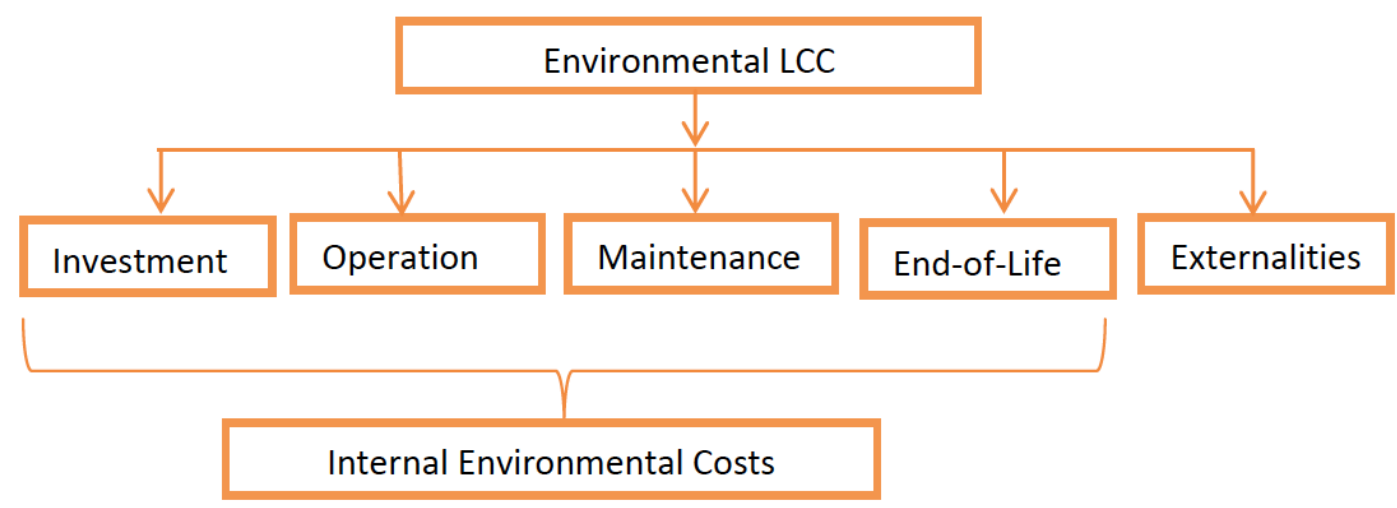


Table 1: Basic Information on TPPs of BH Regarding Pollutants Emissions

\begin{tabular}{|c|c|c|c|c|}
\hline $\begin{array}{l}\text { Units of thermal } \\
\text { plants }\end{array}$ & In operation since & $\begin{array}{l}\text { Planned year of } \\
\text { decommissioning }\end{array}$ & $\begin{array}{l}\text { Installed power } \\
{[\text { [MW] }}\end{array}$ & $\begin{array}{c}\text { Specific consumption } \\
{[\mathrm{kJ} / \mathrm{kWh}]}\end{array}$ \\
\hline TPPT U3 & 1966 & 2013 & 100 & 13,982 \\
\hline TPPT U4 & 1971 & 2018 & 200 & 11,650 \\
\hline TPPT U5 & 1974 & 2023 & 200 & 11,500 \\
\hline TPPT U6 & 1978 & 2026 & 215 & 11,200 \\
\hline TPPK U5 & 1969 & 2018 & 110 & 11,300 \\
\hline TPPK U6 & 1977 & 2026 & 110 & 11,300 \\
\hline TPPK U7 & 1988 & 2030 & 230 & 11,000 \\
\hline TPPU U1 & 1985 & 2032 & 300 & 11,032 \\
\hline TPPG U1 & 1983 & 2032 & 300 & 11,570 \\
\hline $\begin{array}{l}\text { Units of thermal } \\
\text { plants }\end{array}$ & $\begin{array}{c}\text { Emission of } \mathrm{SO}_{2} \\
{\left[\mathrm{mg} / \mathrm{m}^{3}\right]}\end{array}$ & $\begin{array}{c}\mathrm{SO}_{2} \text { limitations according } \\
\text { to } \mathrm{LCPD}^{*} \\
{\left[\mathrm{mg} / \mathrm{m}^{3}\right]}\end{array}$ & $\begin{array}{l}\text { Emission of NOx } \\
\qquad\left[\mathrm{mg} / \mathrm{m}^{3}\right]\end{array}$ & $\begin{array}{c}\text { NOx limitations } \\
\text { according to LCPD* } \\
{\left[\mathrm{mg} / \mathrm{m}^{3}\right]}\end{array}$ \\
\hline TPPT U5 & $2,496^{1}$ & 400 & 290 & 200 \\
\hline TPPT U6 & $4,616^{1}$ & 400 & 600 & 200 \\
\hline TPPK U6 & $8,200^{2}$ & 1080 & 800 & 600 \\
\hline TPPK U7 & $8,400^{2}$ & 516 & 700 & 200 \\
\hline TPPU U1 & $25,000-11,000^{3}$ & 400 & 600 & 200 \\
\hline TPPG U1 & $1,700^{3}$ & 400 & 850 & 200 \\
\hline
\end{tabular}

${ }^{1}[11] ;{ }^{2}[5],{ }^{3}[12]$.

*It must be stressed that the LCPD is outdated and entered into force IE Directive stipulating more stringent emission limits. During the negotiations in Vienna with the Energy Community BH's team have adopted measures for emissions increasing so the command and control measure for emission increasing have become obligations for the country $\mathrm{BH}$.

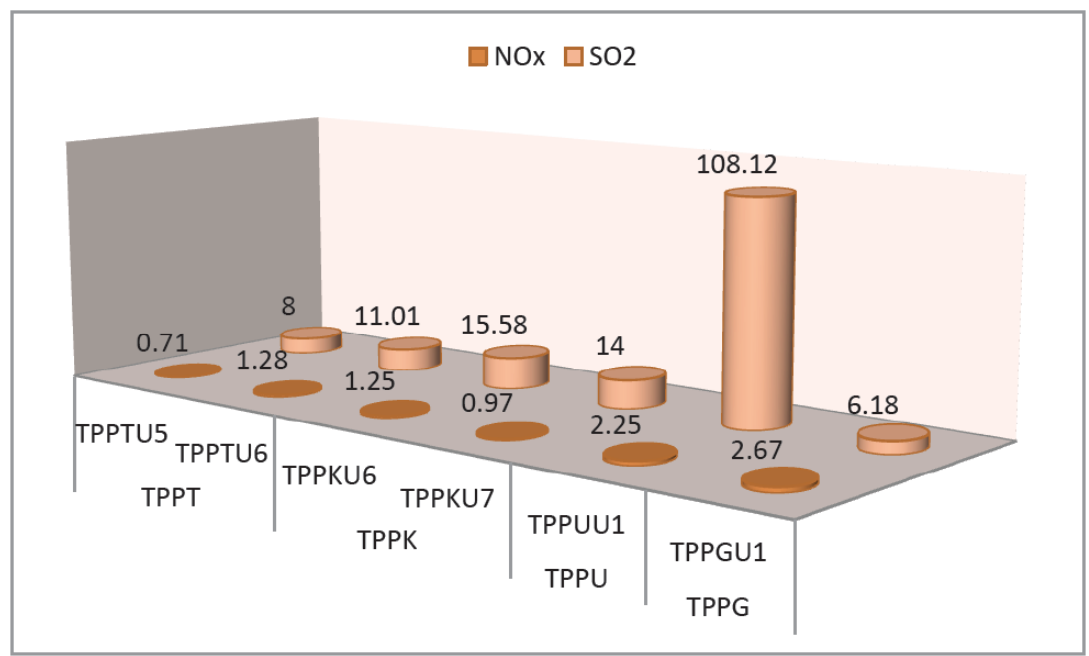

Figure 1: External costs for BH's thermal power plants due to emissions of $\mathrm{SO}_{2}$ and $\mathrm{NOx}$ calculated by EcoSense Web (Eurocents/kWh).

scenario is used with average meteorological condition. Since the SEE countries and the European Community on October 25, 2005 signed an Energy Community Treaty [15] the country is committed itself to adopting and enforcing the EU Directive on large combustion plant (LCPD) and IED by 2017. BH has to implement the LCPD/IED at all of its coal-fired power plants which means imposing a command control measure i.e. imposing a limit emission value for thermal power plants. So, the second scenario needed for calculation of avoided damages sets emission limit values according the LCPD for existing units in $\mathrm{BH}$. 
According documents "Economics and Cross-Media effects" [16] cost data should preferably be calculated and presented as annual costs. Total annual costs are calculated as sum of annual capital costs (capital costs $x$ capital recovery factor) and net annual operating and maintenance costs.

$C_{a}=C_{0}\left[\frac{r(1+r)^{n}}{(1+r)^{n}-1}\right]+O C$

Where

$$
\begin{gathered}
\mathrm{C}_{\mathrm{a}}=\text { total annual cost } \\
\mathrm{r}=\text { the discount (interest) rate per } \\
\text { period } \\
\text { OC=total net operating and } \\
\text { maintenance cost (constant for } \\
\text { every year) }
\end{gathered}
$$

$$
\begin{gathered}
\mathrm{C}_{0}=\text { the cost at year } 0 \text { (the } \\
\text { base year) } \\
\mathrm{n}=\text { the estimated economic } \\
\text { lifetime of the equipment } \\
\text { in years }
\end{gathered}
$$

In the KEMA study [5] for the needs of TPPK costs have been considered for desulphurization i.e. for DeSOx -wet FGD, dry FGD and semi-dry FGD. It is also important to mention that different technologies for DeSOx have a rather different investment costs: Dry FGD $(123 € / \mathrm{MWe})$ and semi-dry FGD (147 €/MWe) have almost two times lower investment costs than wet FGD (260 €/MWe) and difference in removal efficiency is not so significant. Also, for DeNOx three technologies can be applied: Selective Catalytic Reduction (SCR), Selective Non Catalytic Reduction
(SNCR) and Hybrid (SNCR+in-duct SCR). Investment and O\&M costs are given in Table 2 for all BH's units considered for the retrofitting. In document "Full cost estimates of the use of different energy sources" [17] private costs are given by using two discount rates $(5 \%$ and $10 \%)$. So, for further simplification of presented results authors have chosen discount rate according KEMA study [5].

For better understanding the needed range of investments and OM costs for DeSOx (wet DeSOx and discount rate 9.3) on Figure 2 current generation electricity price and investments costs for thermal power plants units of TPP Tuzla and TPP Kakanj are shown.

Due to recommendation given in Table $\mathbf{3}$ from "Study on the need for modernization of large combustion plants (LCP) in EnC" [18] easily can be observed that recommended technology for DeSOx is wet limestone DeSOx and for DeNOx is SNCR. Units

\begin{tabular}{|c|c|c|c|c|c|c|c|}
\hline \multicolumn{2}{|c|}{$\begin{array}{c}\text { Costs } \\
\text { (Eurocents/kWh) }\end{array}$} & \multicolumn{3}{|c|}{ Investment and O\&M costs for DeSOx } & \multicolumn{3}{|c|}{ Investment costs of DeNOx } \\
\hline Unit & $\begin{array}{c}\text { Discount rate* } \\
(\%)\end{array}$ & wet FGD & dry FGD & semi dry FGD & SCR & SCNR & Hybrid \\
\hline \multirow{2}{*}{ TPPT U5 } & 6.25 & 2.93 & 2.01 & 1.68 & 1.06 & 0.37 & 0.63 \\
\hline & 9.30 & 3.06 & 2.07 & 1.72 & 1.10 & 0.38 & 0.65 \\
\hline TPPT U6 & 9.30 & 2.22 & 1.57 & 1.54 & 0.98 & 0.35 & 0.58 \\
\hline \multirow{2}{*}{ TPPK U6 } & 6.25 & 3.71 & 2.21 & 2.37 & 1.45 & 0.43 & 0.82 \\
\hline & 9.30 & 3.90 & 2.30 & 2.48 & 1.53 & 0.45 & 0.86 \\
\hline TPPK U7 & 6.25 & 2.60 & 1.89 & 1.83 & 0.95 & 0.35 & 0.57 \\
\hline \multirow{2}{*}{ TPPG U1 } & 6.25 & 1.43 & 1.05 & 1.07 & 0.50 & 0.19 & 0.30 \\
\hline & 9.30 & 1.53 & 1.09 & 1.13 & 0.53 & 0.19 & 0.32 \\
\hline
\end{tabular}
with remaining life time of 1 year are not considered for CBA conducting. There is no doubt that any measures to reduce emissions on these units are absolutely not an option.

As it can be seen on Figure 3 installing DeNOx equipment on units of TPPT and TPPK is not economically justified. Only units with significant difference between avoided damages and private cost

Table 2: Investment and O\&M Costs for DeSOx and DeNOx Applied on Existing Thermal Plants Units Based on Electricity Generation of 2010

${ }^{*}$ Discount rate of $6.25 \%$ is used in public enterprise Elektroprivreda $\mathrm{BH}$ for investment calculation and KEMA study recommended a different discount rate for BH energy sector $-9.30 \%$ 


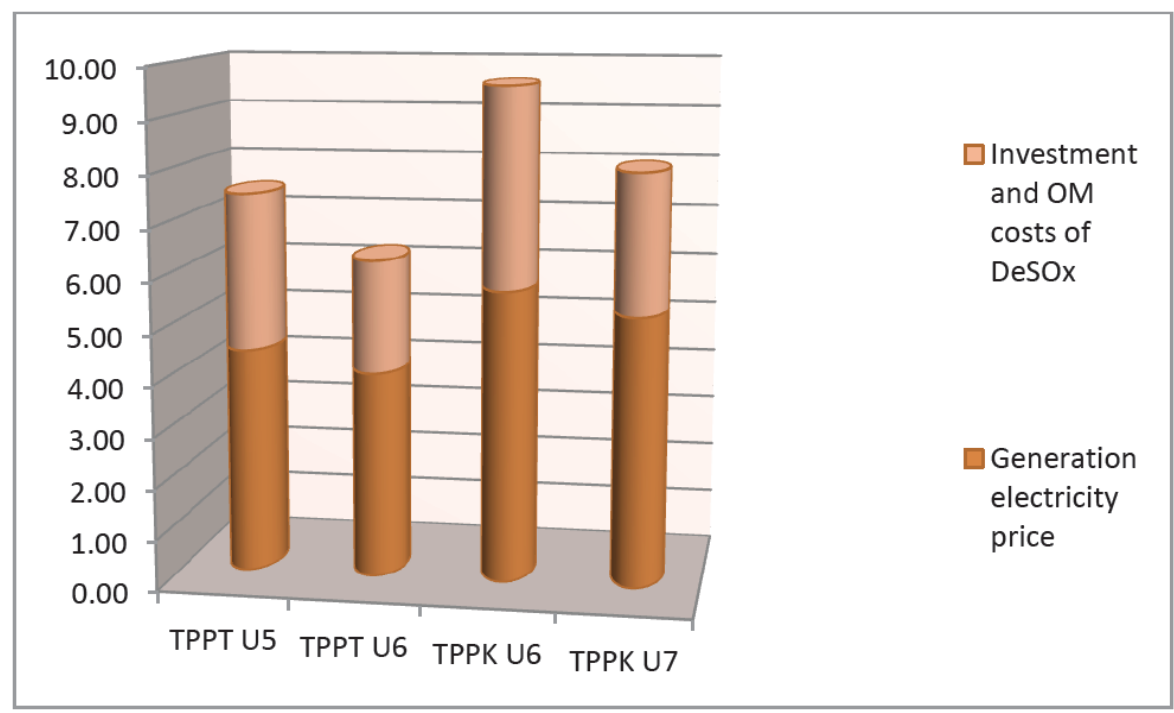

Figure 2: Eventually generation electricity price increment by installing wet DeSOx (Eurocents/kWh).

Table 3: Recommended Measures for BH's Thermal Units for Reaching LCP/IE Directives' ELV

\begin{tabular}{|c|c|c|c|c|c|c|}
\hline \multirow[t]{2}{*}{ Unit } & \multirow{2}{*}{$\begin{array}{c}\text { Capacity } \\
\text { (MW) }\end{array}$} & \multirow{2}{*}{$\begin{array}{c}\begin{array}{c}\text { Remaining life } \\
\text { time }\end{array} \\
\text { from } 2017\end{array}$} & \multicolumn{3}{|c|}{ LCP/IE directive retrofit measures } & \multirow{2}{*}{$\begin{array}{c}\text { Needed funds } \\
\text { LCPD/IED }\end{array}$} \\
\hline & & & Dust & NOx & $\mathrm{SO}_{2}$ & \\
\hline Gacko & 300 & 15 & ESP & $\mathrm{LNB}+\mathrm{OFA}+\mathrm{SNCR}$ & SD & $33.4 / 37.3$ \\
\hline Ugljevik & 300 & 15 & ESP & $\mathrm{LNB}+\mathrm{OFA}+\mathrm{SNCR}$ & WLS & $107.9 / 118.4$ \\
\hline Tuzla 4 & 200 & 1 & ESP & LNB+OFA & SD & $87.8 / 91.6$ \\
\hline Tuzla 5 & 200 & 6 & ESP & LNB+OFA & WLS & \\
\hline Tuzla 6 & 215 & 9 & ESP & LNB+OFA & WLS & \\
\hline Kakanj 5 & 110 & 1 & & LNB+OFA/SCR+SCNR & WLS & $110.3 / 127.4$ \\
\hline Kakanj 6 & 110 & 9 & & LNB/SCR+SNCR & WLS & \\
\hline Kakanj 7 & 230 & 13 & ESP & $\mathrm{SCR}+\mathrm{LNB} / \mathrm{LNB}+\mathrm{SCR}$ & WLS & \\
\hline TOTAL & & & & & & $337.2 / 374.7$ \\
\hline
\end{tabular}

is TPPG U1. For DeSOx situation is quite different especially on TPPU U1. Results of conducted CBA for wet DeSOx and SNCR are shown in Figure 3 for all $\mathrm{BH}$ 's thermal power plants units which are considered for retrofitting. In TPPU there is no adequate equipment installed for emission monitoring and according to the available emission data $\left(25,000-11,000 \mathrm{mg} / \mathrm{m}^{3}\right.$ of $\left.\mathrm{SO}_{2}\right)$ calculation is done for the worst case regarding emission i.e. for the maximal emission.

CBA with additional external costs occurred due to production of limestone and operating of DeSOx.

According "Evaluation of the environmental performance of lime production in Cuba" [9] calcium oxide $(\mathrm{CaO})$, known as lime or quicklime is energy intensive product. The production process of $1 \mathrm{t}$ of lime entails the emission of around 1.2 tonne of $\mathrm{CO}_{2}$ making lime one of the produced materials with highest associated specific emission of $\mathrm{CO}_{2}$. According the same author quantity of consumed electricity and emitted pollutant is given in Table 4.

According KEMA study [5] for units U6 and U7 TPPK of average limestone consumptions are 3.8 and $10.3 \mathrm{t} / \mathrm{h}$. So for 7,000 working hours needed quantity of limestone for TPPK U6 is $26,600 t / y$, and for TPPK U7 is $72,100 t / y$. So with these data it is easy to calculate yearly emission of air pollutant and energy consumption (see Table 5).

If external costs of air pollutant emission from production of limestone calculated according the ExternE methodology i.e. [17] for the BH's situation the value of external costs would be as presented in Table 6. 


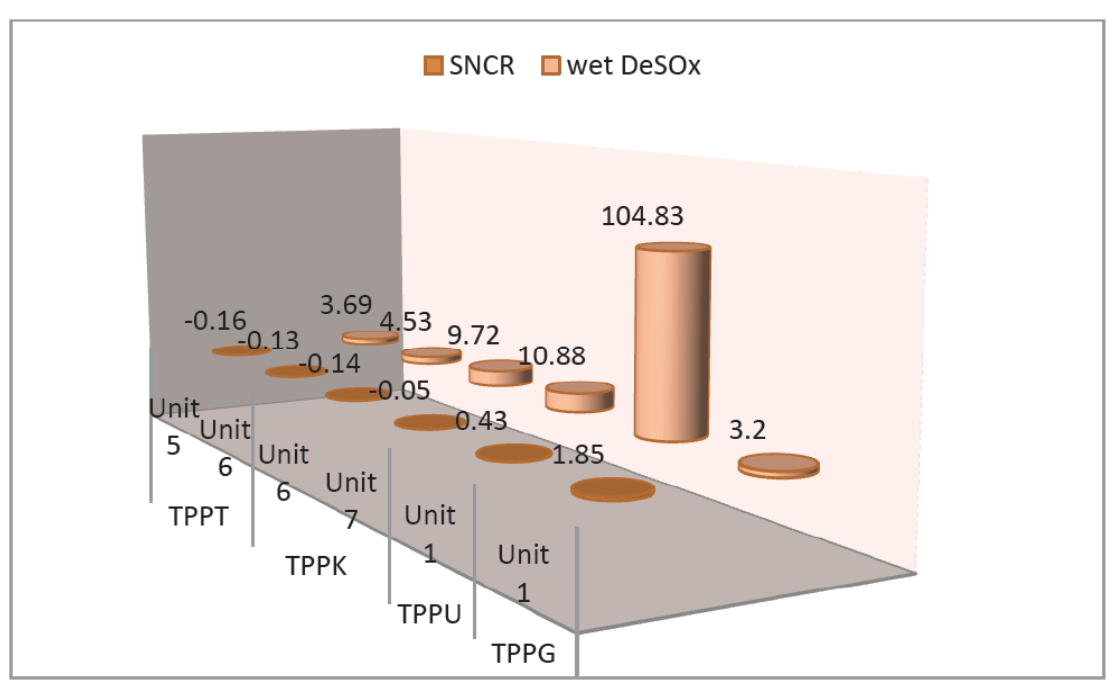

Figure 3: Difference between avoided damages and private costs of installing DeNOx and DeSOx in Eurocents/kWh.

Table 4: Energy and Emissions Inventory of the Production Stage (per ton of $\mathrm{Ca}\left(\mathrm{OH}_{2}\right)$ )

\begin{tabular}{|c|c|c|c|c|c|c|c|}
\hline Stage & Operation & Units & Quantity & Stage & Operation & Units & Quantity \\
\hline \hline 1 & Querrying of lime stone & & & $\mathbf{3}$ & $\mathrm{CO}$ & $\mathrm{kg}$ & 58,8 \\
\hline & Diesel & $\mathrm{MJ}$ & 151 & & $\mathrm{SO}_{2}$ & $\mathrm{~kg}$ & 0.87 \\
\hline & Dust & $\mathrm{kg}$ & 0.46 & & $\mathrm{NOx}$ & $\mathrm{kg}$ & 0.87 \\
\hline 2 & Crushing and screeninig & & & & Dust & $\mathrm{kg}$ & 1.74 \\
\hline & Electricity & $\mathrm{kWh}$ & 1.78 & $\mathbf{4}$ & Hydration and classification & & \\
\hline & Dust & $\mathrm{kg}$ & 0.03 & & Electricity & $\mathrm{kWh}$ & 13.6 \\
\hline 3 & Calcination & & & & Dust & $\mathrm{kg}$ & 51 \\
\hline & Fuel oil & $\mathrm{MJ}$ & 4,481 & $\mathbf{5}$ & Packaging & & \\
\hline & Electricity & $\mathrm{kWh}$ & 19.8 & & Electricity & $\mathrm{kWh}$ & 0.3 \\
\hline & $\mathrm{CO}_{2}$ & $\mathrm{~kg}$ & 973 & & Packing bags & $\mathrm{kg}$ & 4.6 \\
\hline
\end{tabular}

Table 5: Energy and Emissions Inventory of the Production Stage (per ton of $\mathrm{Ca}\left(\mathrm{OH}_{2}\right)$ ) for TPPK

\begin{tabular}{|c|c|c|c|c|}
\hline & & Units & TPPK Unit 6 & TPPK Unit 7 \\
\hline \multirow{2}{*}{ Querrying of lime stone } & Diesel & MJ & $4,016,600$ & $10,887,100$ \\
\hline & Dust & $\mathrm{kg}$ & 12,236 & 33,166 \\
\hline \multirow{2}{*}{ Crushing and screeninig } & Electricity & kWh & 47,348 & 128,338 \\
\hline & Dust & $\mathrm{kg}$ & 798 & 2,163 \\
\hline \multirow{7}{*}{ Calcination } & Fuel oil & MJ & $119,194,600$ & $323,080,100$ \\
\hline & Electricity & $\mathrm{kWh}$ & 526,680 & $1,427,580$ \\
\hline & $\mathrm{CO}_{2}$ & $\mathrm{~kg}$ & $25,881,800$ & $70,153,300$ \\
\hline & $\mathrm{CO}$ & $\mathrm{kg}$ & $1,564,080$ & $4,239,480$ \\
\hline & $\mathrm{SO}_{2}$ & $\mathrm{~kg}$ & 23,142 & 62,727 \\
\hline & NOx & $\mathrm{kg}$ & 23,142 & 62,727 \\
\hline & Dust & $\mathrm{kg}$ & 46,284 & 125,454 \\
\hline \multirow{2}{*}{$\begin{array}{l}\text { Hydration and } \\
\text { classification }\end{array}$} & Electricity & kWh & 361,760 & 980,560 \\
\hline & Dust & $\mathrm{kg}$ & $1,356,600$ & $3,677,100$ \\
\hline \multirow{2}{*}{ Packaging } & Electricity & kWh & 7,980 & 21,630 \\
\hline & Packing bags & $\mathrm{kg}$ & 122,360 & 331,660 \\
\hline
\end{tabular}


Table 6: External Costs Due to Limestone Production and DeSOx Operation

\begin{tabular}{|c|c|c|c|c|}
\hline & \multicolumn{2}{|c|}{ If toxicity of dust equal toxicity PPM $\mathbf{~}_{\mathbf{2}}$} & \multicolumn{2}{|c|}{ If toxicity of dust is equal toxicity of PPMco } \\
\hline & TPPK U6 & TPPK U7 & TPPK U6 & TPPK U7 \\
\hline \hline Atmospheric emission of calcination & $1,359,371$ & $3,684,611$ & $1,359,371$ & $3,684,611$ \\
\hline $\begin{array}{c}\text { Calcination + Hydration and } \\
\text { classification (dust emission) }\end{array}$ & $18,070,275$ & $48,979,957$ & $4,119,373$ & $5,744,615$ \\
\hline Electricity for production of limestone & 42,283 & 113,201 & 471,605 & 113,201 \\
\hline $\begin{array}{c}\text { External costs due to wet DeSOx } \\
\text { electricity consumption }\end{array}$ & 471,605 & 910,514 & 217,854 & 510,514 \\
\hline $\begin{array}{c}\text { External costs due to emission of } \\
\text { CO2 }\end{array}$ & 217,854 & 586,530 & 586,530 \\
\hline
\end{tabular}

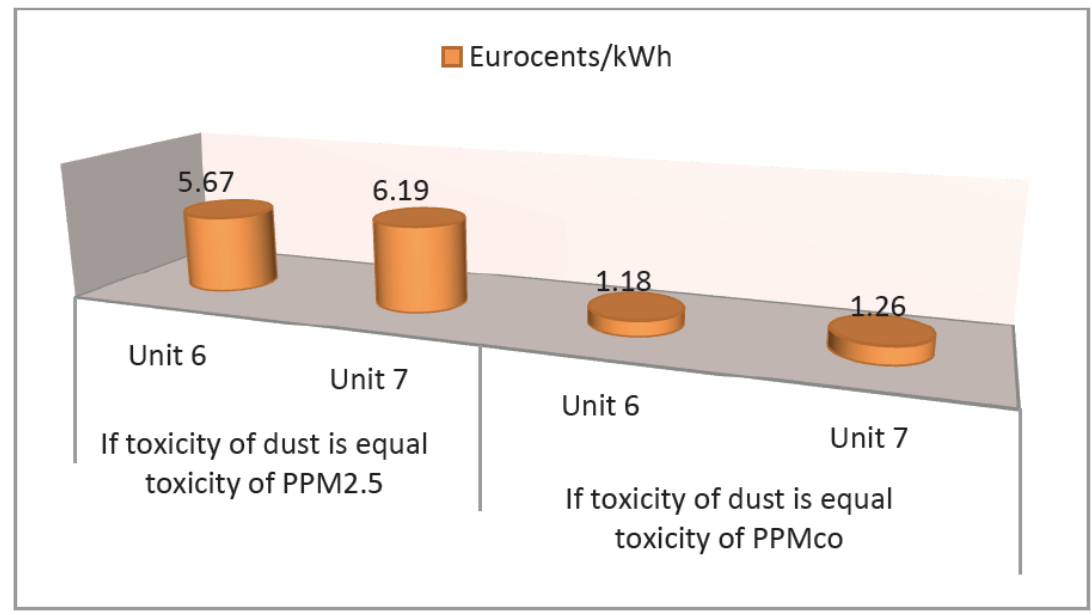

Figure 4: External costs due to DeSOx operation for two scenarios for dust toxicity.

By exploring available literature about external costs due to emission of dust during the process of lime production no values were found. So, authors for the values of external costs of dust emission into the air have chosen the value from [17] $\mathrm{PPM}_{2.5}$ and for PPMco. The difference is significant because $\mathrm{PPM}_{2.5}$ causes external costs (for $\mathrm{BH}$ and for 2010) in amount 12,201 EUR/t and PPMco in amount of 443 EUR/t. So, the calculation is done for both toxicities. External cost due to emission of $\mathrm{CO} 2$ is 19 EUR/t. External costs due to emission of SO2 and NOx were taken also from CASES in amount of 6,387 EUR/t and 6,702 EUR/t. Based on values from Table 6 it is possible to calculate external cost per kWh for units 6 and 7 of TPPK (see Figure 4).

The toxicity of emitted dust from limestone production has a great impact on external costs and further calculation is done by using both values of external costs. KEMA study [5] regarding toxicological properties of material stated that "chronic exposure to respirable limestone dust at levels exceeding limits has caused silicosis, a serious and progressive pneumoconiosis that can be disabling, and lead to death. Symptoms may appear at any time; even years after exposure has ceased". So, it is easy to conclude that limestone dust has seriously impact on human health but difficulties occurred when monetised damage should be added in CBA. Finally, CBA of imposing abatement equipment for DeSOx on TPPK U6 and TPPK U7 is done for different external costs decreased due to cogeneration on two units of TPPK (see Figure 5).

Assumption based on the expansion of consumption of thermal energy in town of TPPK and the surrounding towns (Zenica, Visoko) are made. The scenarios with relatively high decreasing of external costs $(20,30$ and $40 \%)$ have justification in the fact that the cogeneration eliminated many low sources of emission from fossil fuel burning pollution in those cities. It must be mentioned that only external costs due to emission of air pollutants (PPM, $\mathrm{SO}_{2}, \mathrm{NOx}$ and $\mathrm{CO}_{2}$ ) during limestone production and electricity consumption are considered in CBA. According Feng, C. et al. [10] air emissions are not the only impact on 


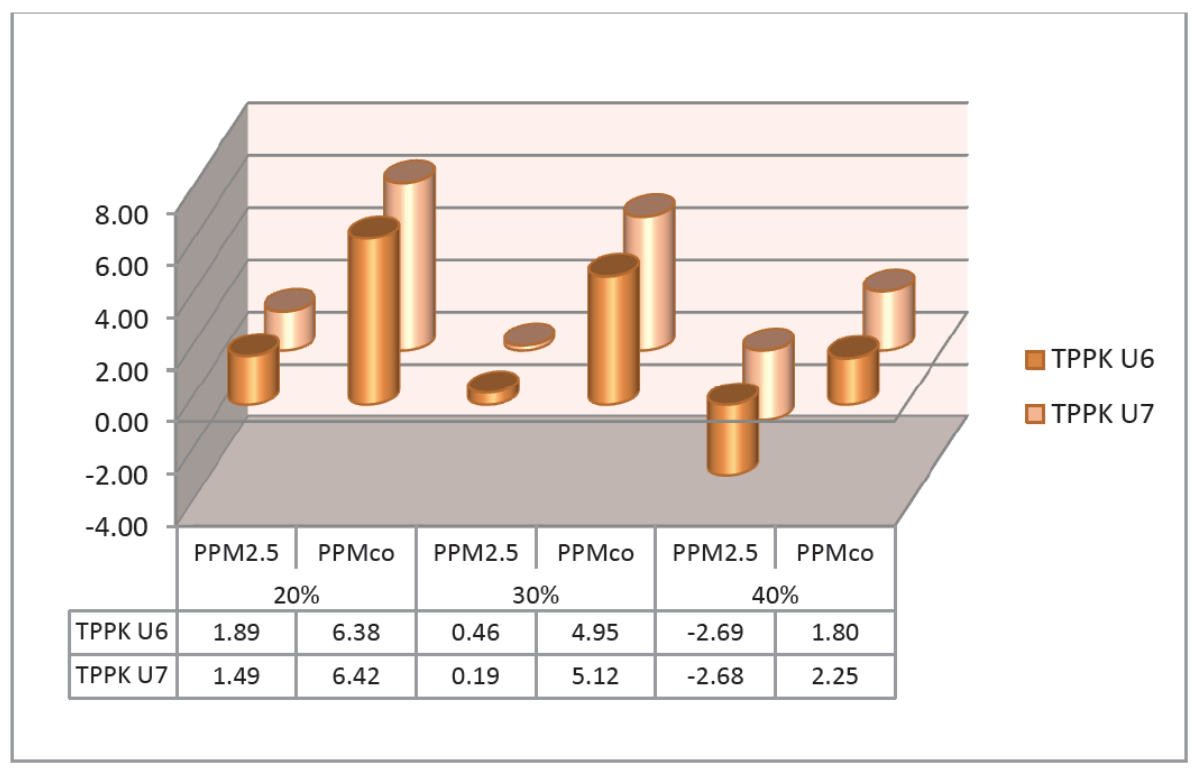

Figure 5: Difference between avoided damages decreased due to cogeneration and private costs increased for external costs due to lime stone production and operating of DeSOx in Eurocents/kWh for thermal units of TPP Kakanj in Bosnia and Herzegovina.

Table 7: Resource consumption and environmental emissions for wet DeSOx-LCA

\begin{tabular}{|c|c|c|c|c|c|c|c|}
\hline & Item & Unit & wet DeSOx & & Item & Unit & wet DeSOx \\
\hline \multirow{6}{*}{ 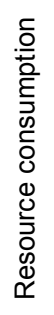 } & Electricity & GJ & 506.408 & \multirow{6}{*}{ 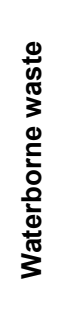 } & Suspended substance & $\mathrm{t}$ & 212 \\
\hline & Coal & GJ & 66.902 & & $\mathrm{NH}_{4}$ & $\mathrm{t}$ & 1.74 \\
\hline & Diesel & GJ & 32.165 & & COD & $\mathrm{t}$ & 0.50 \\
\hline & Fuel oil & GJ & 5.934 & & BOD & $\mathrm{t}$ & 0.01 \\
\hline & Crude oil & GJ & 11.046 & & Phenylic acid & $\mathrm{t}$ & 0.01 \\
\hline & Water & $\mathrm{m}^{3}$ & 630.375 & & $\mathrm{Na}+$ & $\mathrm{t}$ & 0.67 \\
\hline \multirow{10}{*}{ 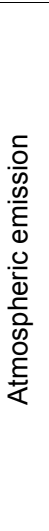 } & Dust & $\mathrm{t}$ & 254 & \multirow{3}{*}{ 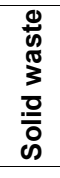 } & Slag & $\mathrm{t}$ & 7.009 \\
\hline & $\mathrm{CO}$ & $\mathrm{t}$ & 194 & & Mixed solid waste & $\mathrm{t}$ & 46.200 \\
\hline & $\mathrm{CO}_{2}$ & $\mathrm{t}$ & 82.402 & & Ash & $\mathrm{t}$ & 519 \\
\hline & $\mathrm{SO}_{2}$ & $\mathrm{t}$ & 2.597 & & & & \\
\hline & NOx & $\mathrm{t}$ & 377 & & & & \\
\hline & $\mathrm{CxHy}$ & $\mathrm{t}$ & 3 & & & & \\
\hline & $\mathrm{CH}_{4}$ & $\mathrm{t}$ & 31 & & & & \\
\hline & $\mathrm{H}_{2} \mathrm{~S}$ & $\mathrm{t}$ & 0.15 & & & & \\
\hline & $\mathrm{HCl}$ & $\mathrm{t}$ & 1.54 & & & & \\
\hline & $\mathrm{HC}$ & $\mathrm{t}$ & 0.12 & & & & \\
\hline
\end{tabular}

human health and environment (see Table 7) but scientific knowledge about external costs is still limited and because of that fact all impacts occurred during the limestone production and operating of DeSOx cannot be monetized.

For CBA conducting external costs of electricity consumption and atmospheric emission of dust, $\mathrm{CO}_{2}$,
$\mathrm{SO}_{2}$ and $\mathrm{NOx}$ are taken into account. Consumption of coal, diesel, fuel oil, crude oil and water are not included. External costs of waterborne waste and solid waste are not considered at all.

The main residue of wet DeSOx is gypsum. The amount of gypsum produced can also be calculated accurately from the SO2 removed (or limestone used). 
For TPPK U6 and U7 produced gypsum quantity is the $6.8 \mathrm{t} / \mathrm{h}$ and the $18.7 \mathrm{t} / \mathrm{h}$ what yearly mean quantity of $47.600 \mathrm{t}$ and $130.900 \mathrm{t}$, respectively. Gypsum can be used as a basic material in several industries. The guarantee values that are commonly valid in Western Europe have to be reached. It is stated in KEMA study [5]: "it is expected that it will take some time from start up before this quality can be reached". Also, because the market situation is not known, it will be assumed that the gypsum has to be deposited on the existing disposal site, mixed up with the fly ashes of the boilers. The fact that there is a mine of natural gypsum in $\mathrm{BH}$ should be also considered because the gypsum should be disposed on already filled disposal site. The mentioned can be monetised too and because of that cannot be considered in conducted CBA.

The amount of sludge is very low, compared to the gypsum amount, but disposal on the existing site is expected to be not allowed. The sludge will contain high levels of heavy metals and is leachable. In Western Europe, this sludge has to be disposed at special sites, at much higher costs compared to fly ash or gypsum. So, the KEMA study [5] considered this in the economic part. The Energy Community Study [18] did not consider this fact in their study for SEE countries. But in the Energy Community Study [18] it is stated: "There are generally two types of wet limestone scrubber: forced oxidation and natural oxidation. In the limestone with forced oxidation (LSFO) system, air is introduced into the bottom of the absorber to force oxidation of calcium sulphate to calcium sulphate while gypsum is obtained as a by-product. When implementing wet limestone DeSOx systems on an existing installation, the flue gas path from the inlet of the absorber to the stack may need to be modified to protect against corrosion and acid attack. In most retrofit units, new stacks are required. This additional cost is not considered but it has to be added on some way to investments cost. Due to lack of data in this paper this cost did not considered too.

Decommission costs for the utilities for DeSOx and DeNOx in $\mathrm{BH}$ are also not included in the investment costs. The usual life time of those utilities is about 30 years but in the case of $\mathrm{BH}$ they will be in operation only for the 15 years as maximum and this fact may influence the investment cost. Although the large part of DeSOx and DeNOx utilities can be sold for recycling but still some parts of utilities will for sure ended in nature (as industrial waste) causing external costs.

When implementing wet limestone FGD systems on the existing utilities, the flue gas path from the inlet of the absorber to the stack may need to be modified to protect against corrosion and acid attack. In most retrofit units, new stacks are required. As the DeSOx system requires considerable space, retrofitting may be more expensive in cases where there is a lack of available space [18]. These costs are also haven't been considered.

In the KEMA study [5] one can see that installing a hybrid DeNOx and semi-dry FGD at TPPK U7 will give a negative NPV of 62 million EUR in 2026. The main parameters of the calculations are: used discount rate for calculation $9.3 \%$, investment cost 33.9 million EUR, value of electricity $48.45 \mathrm{EUR} / \mathrm{MWh}$, and 8 years period

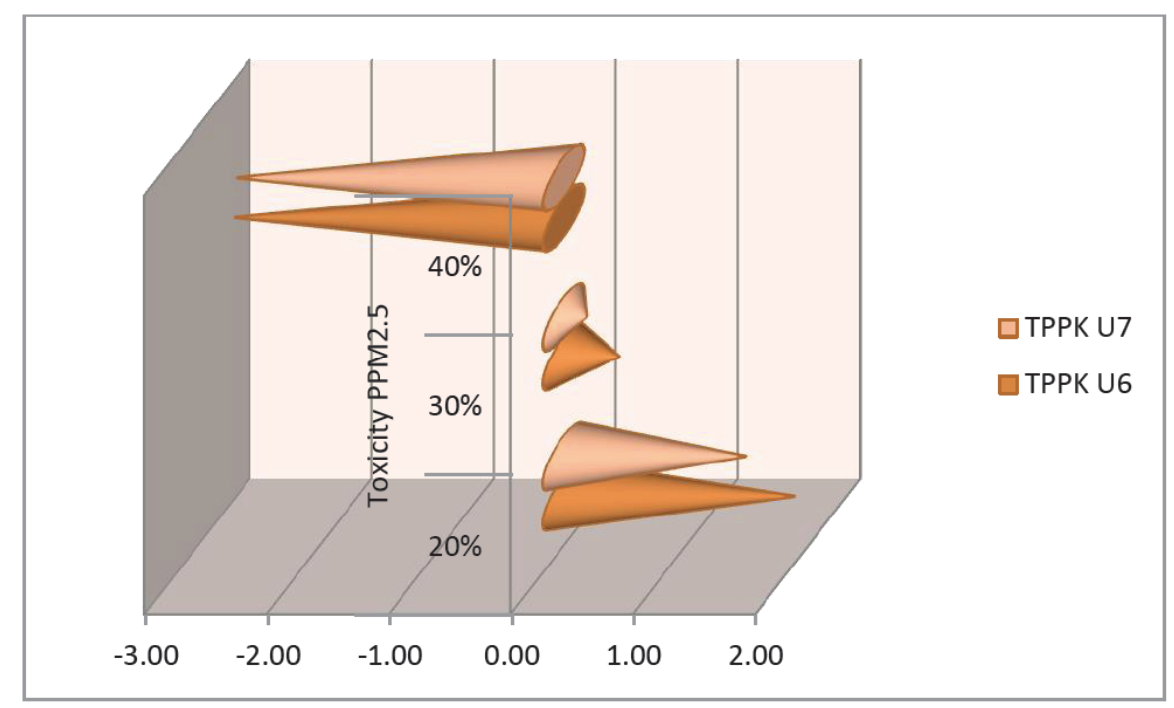

Figure 6: Difference between avoided damages and overall costs (private plus additional external costs) for different rate of decreased external costs due to cogeneration (Eurocents/kWh). 
of operation. The NPV will be zero if the electricity selling price will be increased at January 1, 2018 with 18.1 EUR/MWh to a total electricity price of 72.64 EUR/MWh. Almost is the same with TPPKU6 with selling price increasing by 11.81 EUR/MWh [5]. Increasing of electricity price would be a kind of economic shock that might increase the rate of poverty (in $\mathrm{BH}$ there is $20 \%$ of poor people and $10 \%$ of people by their incomes is near to the poverty line).

Results of conducted CBA for high toxicity of limestone (equal to toxicity of $\mathrm{PPM}_{2.5}$ ) and for decreased external costs due to cogeneration on the Figure 7 are shown. Obtained results of the CBA and the fact that all impacts still cannot be monetised on scientifically acceptable manner reveals that the CBA cannot be the only parameter for the decision making. This is already known fact in environment protection and decision making process for the energy policies.

According KEMA study [5] toxicity of limestone dust is more near toxicity of $\mathrm{PPM}_{2.5}$ rather than toxicity of PPMco, so authors have chosen to show on Figure 6 differences between avoided damages and all imposed costs (private plus additional external costs) for different increased external costs due to cogeneration. It is easy to observe that overall social benefits with decreased external costs due to cogeneration are not so significant (app. 1 Eurocent $/ \mathrm{kWh}$ ) and in the case of $40 \%$ decreased external costs there is no benefits but only costs for society. According to Rabl, A. and Holland, M., [19] because of doubly uncertainty (uncertainties of damage costs as of abatement costs) the authors of any study should be careful when present and document the assumptions and the results with sufficient detail. On Figure 7 costs which are taken into account and impacts which are not taken into account are shown. So, according Van den Bergh [20] sustainability does not require zero externalities in general and also, eliminating of one type of externality usually generates other and authors of this paper has concluded that additional external costs should take a place in CBA especially for wet DeSOx. All other not monetised impact should also be considered either through analyses or through conducting of multi criteria analyses.

\section{CONCLUSION}

Environmental CBA is well known and now widely used for decision making in energy policies. But it is questionable when retrofit of existing thermal units is issue how to quantify all impacts. Through this work it is shown that eliminating one type of externality i.e.

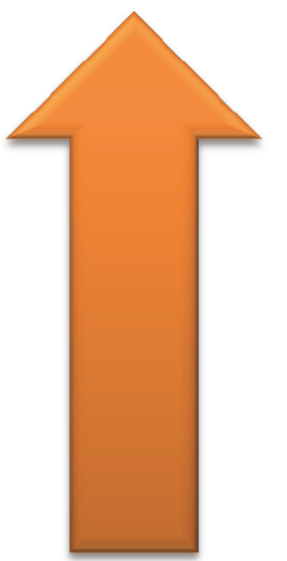

Taken into account in CBA

- External environmental costs occurred due to electricity generation and avoided damages of two scenarios regarding $\mathrm{SO}_{2}$ emission

-Investment costs and O\&M costs of DeSOx (including disposal of sludge from DeSOx)

-Some of external environmental costs occured due to limestone production (air emission)

-External environmental costs due to DeSOx's electricity consumption
Not taken into account in CBA

- External environmental costs due to emission into the water

-External environmental costs due to emission of pollutant not monetised in ExternE like $\mathrm{HCl}$

-Investment costs of some changes on stuck and availability of space

- DeSOx decommission costs

-External environmental costs due to disposing some parts of DeSOx utilities in land field (i.e. nature)

- Electricity price increasing in developing country (SLCA)

- Gypsum has to be deposited on the existing disposal site, mixed up with the fly ashes of the boilers until the quality of gypsum is reached

-Destruction of the landscape due to limestone mining

-Steel production for DeSOx utilities

Figure 7: The overview of costs (or fact) taken and not taken into account in conducted CBA. 
eliminating $\mathrm{SO}_{2}$ from fossil flues combustion generates other externalities i.e. in this case external costs are arising from the limestone production and operating of DeSOx utility itself. It is shown that other negative impacts trough DeSOx process still cannot be adequately monetised for using in CBA. Authors of this paper have conducted CBA with additional external costs and it is shown that external costs from operating of DeSOx have some impact on results of CBA. Toxicity of limestone dust is not defined through ExternE methodology so CBA is done with toxicity of limestone dust equal to $\mathrm{PPM}_{2.5}$ and $\mathrm{PPM}_{\mathrm{co}}$. Results of CBA considerably vary depending on used toxicity of limestone dust and decreased external costs due to cogeneration. Also, there are still non monetized impacts making decision process based only on CBA results more uncertain. Where there is sufficient technical and financial data, knowledge and skills some of costs not taken into account in CBA (like investment costs of some changes on stuck and availability of space, DeSOx decommission costs) can be calculated. But impacts like electricity price increasing in one country or destruction of the landscape due to limestone mining in specific location cannot be taken into account in CBA. Mentioned differ according preferences of decision makers and as tool only MCDA can be used to show the (social) preferences. So, using only CBA in decision making processes does not include the two pillars of sustainable development economic and social impacts. For decision making process it seems reasonable to analyse shifting of external costs from one area to another i.e. include the added external costs occurring trough process of abatement emission.

\section{GLOSSARY}

Acquis accumulated legislation of EU law

$\mathrm{BH} \quad$ Bosnia and Herzegovina

DeNOx Denitrification

DeSOx Desulphurization

EnC Energy Community

FGD Flue gas desulphurization

Hybrid SNCR+in-duct SCR

LCA Life Cycle Assessment

LRTAP Long-Range Transboundary Air Pollution
LNB Low NOx burners

MW $\quad 10^{6} \mathrm{~W}$

OFA Over-fire air

PC Private cost

SEE South Eastern Europe

SD Semi-dry FGD

SCR Selective Catalytic Reduction

SNCR Selective Non Catalytic Reduction

TPPG Thermal power plant Gacko

TPPK Thermal power plant Kakanj

TPPT Thermal power plant Tuzla

TPPU Thermal power plant Ugljevik

U Unit

WLS Wet limestone FGD

\section{REFERENCES}

[1] European Commission, ExternE-Externalities of Energy, Methodology 2005Update, 2005, Available from http://maxima.ier.uni-stuttgart.de/brussels/methup05.pdf

[2] Erwin MS, et al. Life Cycle costing in Sustainability Assessment-A Case Study of Remanufactured Alternators. Sustainability 2011; 3: 2268-2288. https://doi.org/10.3390/su3112268

[3] UNEP, Guidelines for social life cycle assessment of products, ISBN: 978-92-807-3021-0, 2009.

[4] IER (Institutfuer Energiewirtschaft und Rationelle Energieanwendung), EcoSense Web V1.2, User's Manual, Description of Updated and Extended Draft Tools for Detailed Site-dependent Assessment of External Costs, 2007, /http://ecosenseweb.ier.uni-stuttgart.de/index.htmlS

[5] KEMA, Study to develop the design for reduction of Sulphur dioxide and Nitrogen oxide emissions at Kakanj TPP, Arnhem, 2010.

[6] European Commission, Integrated pollution prevention and control, Reference document on economics and cross-media effects, July 2006.

[7] Eyre, N., External costs: what do they mean for energy policy? Elsevier Energy Policy 1997; 25(1): 85-95.

[8] http://ec.europa.eu/environment/gpp/lcc.htm

[9] Gutiérrez AS, et al. Evaluation of the environmental performance of lime production in Cuba. Journal of Cleaner production 2012; 31: 126-136. Elsevier, 2012

[10] Feng $C$, et al. Comparative life cycle assessment of flue gas desulphurization technologies in China. Elsevier, Journal of Cleaner Production 2013.

[11] Ekonerg, Study measures for reducing emissions of pollutants in the air from TPP Tuzla, Zagreb, 2010.

[12] Email message from Borivoje Vujičić (EP RS), 17/06/2011 
[13] Friedrich R, Rabl A, Spadaro J. Quantifying the Costs of Air Pollution: the ExternE Project of the EC, Published in Pollution Atmosphe' rique, Dec. 2001, Special bilingual issue "Combien vaut l'air propre-how much is clean air worth", 200, pp. 77-104.

[14] Dimitrijevic Z, Tatic K. The economically acceptable scenarios for investments in desulphurization and denitrification on existing coal-fired units in Bosnia and Herzegovina. Elsevier, Energy Policy 2012; 49: 597-607. https://doi.org/10.1016/j.enpol.2012.06.064

[15] Energy Community, Treaty establishing the Energy Community, Athens, October 25, 2005.

[16] European Commission 2006, Integrated pollution prevention and control, Reference document on economics and crossmedia effects, July 2006.
[17] CASES, External Costs Database (Euro/ton values) [D.2.2], 2008, http://www.feem-project.net/cases/downloads presentation.phpS (accessed September 2008).

[18] Energy Community, Study on the need for modernization of large combustion plants (LCP) in EnC, South East European Consultants, Ltd., November 2013.

[19] Rabl A, Holland M. Environmental Assessment Framework for Policy Applications: Life Cycle Assessment, External costs and Multi criteria Analysis. Journal of Environmental Planning and Management 2008; 51(1): 81-105. https://doi.org/10.1080/09640560701712275

[20] van der Berg J. Externality or sustainability economics? Elsevier, Ecological Economics 2010; 69: 2047-2052. https://doi.org/10.1016/j.ecolecon.2010.02.009 